Journal of Social and Development Sciences

Vol. 3, No. 2, pp. 59-68, Feb 2012 (ISSN 2221-1152)

\title{
The Impact of FDI on Economic Development of Pakistan
}

\author{
Muhammad Tahir Mahmood ${ }^{1}$, Kashif-ur-Rehman² \\ ${ }^{1}$ Foundation University Islamabad, Pakistan \\ 2Iqra University, Islamabad, Pakistan \\ *drkashif@iqraisb.edu.pk
}

\begin{abstract}
The foreign direct investment has made its position better as a bundle of benefits during the last three decades at the global level. The ultimate result of its benefits for the recipient countries is often sought in term of economic development. Such results do not appear in the same fashion in all recipient economies and so provide the space to investigate this nexus at country level. This study is an endeavor to examine empirically the impact of FDI on economic development of Pakistan. For this purpose, the time series data covering the period (1971-2009) were used. For data analysis, the bound testing approach to co integration within the framework of the Autoregressive Distributed Lag (ARDL) was utilized. The findings of the study supported the hypothesis of positive impact of FDI on economic development of Pakistan. The results also endorsed the views that the FDI is more effective than that of domestic investment.
\end{abstract}

\section{Keywords: Foreign Direct Investment; Domestic Investment; Economic Development}

\section{Introduction}

The Foreign Direct Investment (FDI) is a type of foreign investment, which is assumed to play a vital role for its being a source of capital, employment, knowledge, technology, skills and ability. The FDI is considered a support for the countries having small capital for investment. It is undertaken to bypass the trade restrictions imposed by the government. The FDI is argued to have enhanced the economic growth of the host country (the FDI recipients) through financial support, knowledge spillover, and technological diffusion. There exists abundant literature focusing on the impact of the FDI on the host countries. This literature portrays diverse results. The variation exists not only between the developing and the developed countries but also within categories. Among the developing countries in Asia, Singapore, Hong Kong, Taiwan, and South Korea show better roles in realizing the potential of the FDI than that of in Pakistan and India. On the contrary, the FDI also has its cost for the host countries and that effect cannot be overlooked. This cost includes the unpleasant effects of the Multinational Enterprises (MNEs). The MNEs can affect the competition within the host countries through monopolizing the market, and influence the national sovereignty by putting pressure on decision making of the host country. The repatriation of profit and imports of the input may affect the balance of payment adversely. In the literature, the studies like Griffin (1970), Weisskof (1972), and Haddad and Harrison (1993) supported this view. Despite some negative aspects of the FDI, its importance increased gradually during the last three decades. The developing countries are changing their policies gradually to attract the FDI. As an example of FDI orientated efforts, Dutta (2005) reported that Chinese economic reforms like allowing $100 \%$ ownership and profit repatriation made her a foreign investment friendly economy. Due to such policies, China attracted US $\$ 72406$ million as FDI, which was second highest after $\$ 99443$ million attained by United States in the same period. The newly industrialized economies (NIEs) of Hong Kong, Republic of Korea, Singapore, and Taipei (China) are the best examples of the luring effects of the FDI. According to the UNCTAD (2006), the FDI flow in India enhanced due to better economic and policy conditions prevailed there. Following this like trend of the developing countries, Pakistan also took a number of steps including the wide-ranging structural reforms like the deepened liberalization, the legal framework modernization, the enhanced E-governance and the effective one-window operation for attracting the FDI (Government of Pakistan, 2006).

The FDI flow in Pakistan accelerated when the policies of privatization and liberalization of the economy were adopted. In 1980, the FDI inflow was $\$ 64$ million (SHRDC, 2007) and due to the efforts of attracting the FDI, the average annual inflow was \$ 463 million during 1990-2000. In 2005, the FDI inflow was \$ 2183 
million (UNCTAD, 2006) that was 34 times of that in 1980. Though this increase looked enormous, but compared with the global FDI inflow, it could not be more than $0.2 \%$. From the very emergence, Pakistan has been facing the problems of the shortage of the financial resources and widening gap between savings and investments. Such problems did not allow the governments of Pakistan to allocate adequate funds for the developmental projects. A gradual increase in the debt serving and widening gap between savings and investments led the government of Pakistan to opt for the FDI. Usually the FDI is regarded as a useful source that is able to fill the gap existing between the domestically available and desired level of: the amount of savings, the foreign exchange, and the revenue collected by the government, and the management skills to achieve the cherished growth and development. The GNP per capita is considered as the one proxy for the measurement of the economic development. The GNP per capita of Pakistan during the period of 1971-2005 increased from $\$ 170$ to $\$ 690$ while during the same period; in Singapore it changed from $\$ 1070$ to $\$ 27580$, in Hong Kong from \$ 1070 to \$27670, and in Malaysia it rose from \$ 420 to \$ 4970. Among the major FDI recipient countries in Asia, Singapore, Hong Kong and Malaysia showed an enormous increase in the GNP per capita as compared to that in Pakistan. Along with other factors like lack of long-term policies, wars and discontinuation of democracy, the weak FDI inflow might have contributed to poor GNP per capita in Pakistan. The above grim picture of facts about the FDI and the GNP per capita in Pakistan openly speaks of this relationship. The purpose of this study is to examine empirically the impact of FDI on economic development of Pakistan for the period (1971-2009). The remaining sections of the paper contain the literature review regarding the theoretical and empirical evidence of FDI impact on economic development of the host country; selection of explanatory variables; model formulation; estimation of model, and then empirical results and conclusion.

\section{Literature Review}

FDI Effects on Economic Development: A Theoretical Review: The FDI may play a vital role in economic development of the host country through employing the people; filling the gap between the savings and the investments; and generating the revenue by paying the taxes. The Neoclassical Economic Theory of the FDI endorses the views that the FDI has a positive impact on the economic development of the host country and it contributes a great deal in social well-being. The FDI influences not only the capital formation but also it generates the revenue for government through taxes and consequently defuses the pressure of the balance of payment (Seid, 2002). It contributes to strengthen the competition, which leads to the efficient allocation of the resources and better management activities. It enlarges the market by integrating the host country's market to the global one. The FDI helps transfer the technology; the managerial, and the marketing skills as well as information from among the advanced countries to the developing ones (Kojima; 1978). The neoclassical theories suggest that the FDI may act as an engine of the economic growth of the host economies through increasing the capital formation; augmenting the employment; promoting the manufacturing growth; bringing the management expertise and established brand name, and providing the skilled labor an access to the international production network. The FDI may result in the transfer of the technology and other spillover effects (Markusen \& Venables; 1999). The FDI-growth nexus can be traced from among the neoclassical type growth theories of Harrod-Domar and Solow and from the endogenous growth theories. Harrod-Domar model is the functional economic relationship whereas the GDP growth depends directly on the national net saving rate and inversely on the national capital-output ratio (Cypher and Dietz, 2004). Harrod (1939) and Domar (1946) (as cited in Sahoo, 2006) explained that in order to flourish, the economies must save and invest a specified proportion of their GNP. The more an economy saves and invests, the faster it grows, but with the provision of decrease in the capital-output ratio. The Solow-type growth model reveals the diminishing return to the capital and the labor in the short-run while a constant return to scale by changing all inputs with the same percentage in the long-term. The progress in the technology as an exogenous variable can affect the production function's position, but its general shape (Cypher \& Dietz, 2004).

In the traditional neoclassical Solow-type model characterized by the diminishing return to the physical capital and the treating technological change as exogenous variable, the FDI may not have any impact on the long-run growth rate. In Solow-type, neoclassical model the technology was assumed to grow at the same rate for all the economies irrespective of the resources and the policies of those economies. In the endogenous growth models, however, the technology is considered an endogenous variable and dependant on the activities and policies of the particular economy. It depends on the rate of the capital formation like the 
physical; the human and research capital, and the organizational and the institutional structure of that economy. These structures influence an economy's capacity to utilize effectively the world pool of knowledge; adapt to it; and eventually make some additions to that knowledge. According to Wang (1990), the human capital plays a positive role for the rate of return of the physical capital. Moreover, the FDI facilitates the technological change and, hence, adds to the economic growth. Walz (1997) studied the FDI in the framework of the endogenous growth model and concluded that knowledge spillover through the MNCs made the innovation profitable in a low wage country. The FDI stimulated the research and development (R \& D) and the growth when the low developed countries were allowed to imitate the technology. Ruffin (1993) highlighted the role and flows of the foreign investment to the Asia-Pacific region using the neoclassical and the exogenous growth model. The foreign investment paid by raising the wages in the capital importing countries. Subsequently, these higher wages benefited the future generations by the capital accumulation. However, that was just a once for all change. The FDI could increase the rate of growth by introducing the new ideas and by lowering the cost of the innovation following the endogenous growth theory. The foreign direct investors were offered to pocket benefits from the new ideas and the host countries expected the spillovers from them of course, the spillover effects might not occur always. The policy of the reserving home market failed to take into account the immense gain from the trade in ideas, which could exceed the usual gains from the trade. That proposition helped understand the rapid growth of the developing countries in Asia and the Pacific region.

The recent growth theories by Lucas (1988) and Rebelo (1991) extended the definition of the capital by including the human capital and the accumulation of expertise. Romer (1990), and Grossman and Helpman (1991) incorporated the know-how capital obtained by the research and the development as a determinant of the growth along with other variables. This role of knowledge capital laid the foundations for the study of the role of the FDI which was considered a package of the capital, the knowledge and the skills. According to the dependency theory, the foreign investment from the developed economies was not in favor of the long term economic growth of the developing countries. The First world nations exploited the Third world nations by extracting labor and other resources at a lower cost and, consequently, pushed them in the prolonging poverty (Khan, 2007). This theory was adopted by many economies like that of the East Asian and the Latin American countries in 1970s. The countries adopting the dependency theory kept themselves away from the foreign capital. Despite having importance during 1960s and 1970s this theory could not dominate over the states' policies. Most of the countries are now trying to surpass others to attract the FDI for the purpose of the economic development.

The FDI and Economic Development: The Empirical Evidence: The MNCs invest in a country following the strategies with the long time horizons and objectives and, once installed, have large sunk costs in the host countries. The FDI is considered to be less volatile than the portfolio investment and other types of international financial flows. For both the reasons, an increasing volume of the FDI often is taken as a vital contribution to the development process. The impact of the FDI on the socio-economic development of the host countries has been investigated rarely. Sharma and Gani (2004) did it for middle and low-income countries during the period 1975-1999. The regression results indicated the positive impact of the FDI on the human development index for both groups of countries. The positive effect, however, was weak enough in both the cases. Sharma and Sharma (2003) developed two alternative econometric models to examine the degree and the dimension of the relationship between the FDI inflows and the GDP, also the FDI outflows and the GDP, both in absolute and per capita terms as well as rates of the growth of the FDI and the GDP taking the data from 29 countries. The study provided an empirical base to the hypothesis that FDI was related directly to the development, as measured by the income. Shabbir and Mahmood (1992) found the significant positive impact of the foreign private investment on the growth rate of the GNP. Reisen and Soto (2001) while comparing the benefits of the private capital inflows suggested the developing countries not to rely solely on the national savings. They observed that foreign direct investment and the portfolio equity inflows played the role to stimulate the long-term growth prospects. For the transitional economies, Zhang (2001) empirically found the positive effects of the FDI on the China's economy. The externality effects of the FDI were significantly positive and supported the observations that the presence of the multinational corporations (MNCs) not only resulted in the technology transfer and diffusion but also facilitated the China's transition toward a market economy. 
While studying the effect of the FDI in Russia, Yudaeva, Kozlov, Melentieva, and Ponomareva (2003) found the foreign owned firms more productive than the Russian firms due to the access to the sophisticated technology and better management. The positive spillover effects of the technology and the management practices were observed on the domestic firms in the same industry but the foreign firms left a negative effect on the firms in the vertically related industry. Poor quality of the supplier damaged the vertical relationship. Baharumshah and Thanoon (2006) studied empirically the effects of the various types of capital inflows on the growth process of eight East-Asian countries including China based on the dynamic panel data. They confirmed the positive effect of the FDI on the economic growth and found the FDI more productive than the domestic investment. The FDI affected the growth process in both the short and the long run. Moreover, the countries that were successful in attracting the FDI invested more and grew faster than those that discouraged FDI. Sahoo (2006) studied the impact of the FDI on the economic growth, the domestic investment, and, the export for five South Asian countries (India, Pakistan, Bangladesh, Sri Lanka and Nepal). The results showed that the FDI had a positive and significant impact on the growth for four South Asian countries but Pakistan. The other supporting factors to the growth were the exports; the gross domestic capital formation, and the infrastructure. A study conducted by Alfaro, Chanda, Ozcan, and Sayek (2006) focused on the financial markets of the host countries while relating the FDI with the economic growth through the backward linkages. They found that the same amount of increase in the FDI generated three times more additional growth in the financially well developed host countries than in the ones being financially poorly-developed ones. Khan (2007) also examined the link between the FDI, domestic financial sector and the economic growth of Pakistan during 1972-2005. It was found that the FDI had on the positive effects on the economic growth both in the short and the long run unless the financial system of the host country was developed up to specific minimum level. Sahoo and Mathiyazhagan (2003) examined the role of the FDI on the growth in India through the export promotion and found a long run relationship among the GDP, the FDI and the export. Moreover, the exports played a better role in the economic growth than that of the FDI. While studying the relationship among the FDI, the trade and the domestic output in Pakistan for the period of 1972 to 2001, Ahmad, Alam and Butt (2004) found a long run relationship.

Through the FDI, the MNEs may play their role in the industrial development by rising up the scale of the operations in the host country industry upstream and downstream. This occurs due to the forward and backward linkages. Markusen \& Venables (1999) stated in their model that MNEs might have affected the domestic industry of the host country positively by developing the linkages with the local firms. According to Lall (1980), the MNEs had a positive effect on the local firms by demanding the high quality inputs; providing the technology; the information and the training, as well as the access to the market. Lensink and Morrissey (2006) studied the effect of the volatility of the FDI inflow on the growth by using the cross section, the panel data and the instrumental variable technique. They found that the volatility of the FDI had a negative impact on the growth. Moreover, the evidence for the positive impact of the FDI on the growth was not the robust one. Khan and Kim (1999) tested an import demand function in order to examine the impact of the FDI on the imports of Pakistan and detected statistically a significant coefficient with the positive sign. On the contrary, for the FDI influence on the exports, the estimated coefficient was statistically insignificant. Their findings suggested that the FDI inflow largely had been directed towards the import substitution industries or the production for the domestic market while a small portion headed for the export oriented industries. By combining the results, it was observed that the FDI worsened the trade balance in Pakistan.

Selection of Explanatory Variables and Model Formulation: At the macroeconomic level, the FDI might contribute significantly to enhance the capital formation; generates revenue for the government through taxes, and defuse the pressure of the balance of payment (Seid, 2002). Shabbir \& Mahmood (1992) analyzed the impact of the foreign private investment on the growth and found its significant positive impact on the growth rate of the GNP. Moreover, since the MNCs invest in a country following the strategies with the long time horizons and objectives and, once installed, have the large sunk costs in the host countries, the FDI is considered as the less volatile than the portfolio investment and other types of international financial flows. For both the reasons, an increasing volume of the FDI is often taken as a vital contribution to the development process. To see as to whether this conjecture is also true for Pakistan has been investigated in this model. For the economic development of Pakistan as the dependent variable and the FDI inflow as the independent variable, the following other variables would be included in the model as the explanatory variables. The physical capital and economic development association has the sufficient evidence in the theoretical and the 
empirical literature. In the growth theories, the domestic capital has been the central point of discussion. It is regarded as the engine for the long run sustained economic growth process. Atique, Ahmad and Azhar (2004), Iqbal and Zahid (1998), Makki and Sumwaru (2004), and Sahoo (2006) found the positive impact of the domestic capital on the economic growth. The reason for using domestic capital and the foreign one separately is that the foreign capital is assumed to be utilized under the advanced technology and management as compared to the domestic capital. Zhang (2001) and Baharumshah \& Thanoon (2006) in China, and Sahoo (2006) in South Asia endorsed these results. The labor force is considered as the life blood of the industries. Sahoo (2006) used the labor force growth as an explanatory variable for the economic growth. Similarly, Khan (2007) used the log of the total labor force when analyzing the effects of the FDI on the economic growth in Pakistan. The exports are considered to be the major contributors to the economic growth. The growth function could be augmented with the inclusion of the exports. Sahoo (2006) supported the nexus of FDI and export-led growth strategies. The exports have been introduced as an additional factor input into the production function following Balasubramanyam, Salisu, and Sapsford (1999). The exports of the goods and the services as a ratio of the GNP also were used by Shabbir \& Mahmood (1992). An increase in the exports is assumed to expand the market for the domestic producers. Moreover, the exports ease the balance of payment constraints as well.

In line with the objectives of the study and on the basis of the preceding theoretical support, the hypothesis developed was as under: H: The FDI inflow influences the economic development of Pakistan positively. On the basis of the theoretical framework in the previous section, to test the influence of FDI and other most relevant variables on economic development of Pakistan, the model formulation was designed as:

$(G N P P C)_{t}=\alpha+\beta_{1}(F D I)_{t}+\beta_{2}(C H K)_{t}+\beta_{3}(X)_{t}+\beta_{4}(L B G R)_{t}+\mu_{t}$

The (GNPPC) t was the change in the per capita GNP and was used as the proxy for the economic development of Pakistan. As Pakistan is a developing country, this proxy was selected following Lekhi (2008) who suggested the per capita GNP as the proxy for the measurement of the economic development for the developing countries. The variable (FDI) ${ }_{t}$ was the foreign direct investment inflow as percentage of the GDP. The $(\mathrm{CHK})_{\mathrm{t}}$ was the change in the stock of the domestic investment as a ratio of the GDP. First, the domestic investment was differenced $\left(\mathrm{CHK}_{\mathrm{t}}-\mathrm{CHK}_{\mathrm{t}-1}\right)$ and then divided by the real $\mathrm{GDP}_{\mathrm{t}}$ to find the change. The $(\mathrm{X}) \mathrm{t}$ was exports of the goods and the services as the percentage of the GDP. The (LBGR) $\mathrm{t}$ was the labor force growth in Pakistan. The data for dependent variable $(G N P P C)_{t}$ and the independent variable $(F D I)_{t}$ and $(\mathrm{CHK})_{t}$ were collected from the State Bank of Pakistan (2005,2010). The exports of the goods and the services as the percentage of the GDP i.e. (X)t were collected from the World Bank (2007). The labor force growth rate (LBGR) was calculated from the Government of Pakistan $(1996,2006)$.

\section{Estimation of the Model}

As the time series data are being used, there always arises a question of stationary of the data. The variables being used are not necessarily integrated of the same order. To examine the relationships described in the equations (1) the bound testing approach to co integration within the framework of the Autoregressive Distributed Lag (ARDL) was used. This approach was developed by Pesaran, Shin and Smith (2001) and then used by Khan (2007) and Duasa (2007). This technique is considered more suitable for the small sample (from 30 to 80 observations) as in this study and employs only the single reduced form equation. This method does not require the time series to be integrated of the order one. They may be of mixed order i.e. I(0) and I(1) or fractionally integrated. This procedure avoids the large number of specification to be made in the standard cointegration test, and in this method, it is possible that different variables may have different optimal lags.

Following the procedure used by Duasa (2007) the ARDL formulation for the equation (1) was as under:

$$
\begin{aligned}
& \Delta \ln (G N P P C)_{t}=\alpha+\sum_{i=1}^{p} \phi_{i} \Delta \ln (G N P P C)_{t-i}+\sum_{i=0}^{p} \theta_{i} \Delta \ln (F D I)_{t-i}+\sum_{i=0}^{p} \lambda_{i} \Delta \ln (C H K)_{t-i} \\
& +\sum_{i=0}^{p} \psi_{i} \Delta \ln (X)_{t-i}+\sum_{i=0}^{p} \gamma_{i} \Delta \ln (L B G R)_{t-i}+\delta_{1} \ln (G N P P C)_{t-1}+\delta_{2} \ln (F D I)_{t-1}
\end{aligned}
$$


$+\delta_{3} \ln (C H K)_{t-1}+\delta_{4} \ln (X)_{t-1}+\delta_{5} \ln (L B G R)_{t-1}+\varepsilon_{t}$

Where $\Delta$ is the difference operator, $\varepsilon_{\mathrm{t}}$ is the random error. All these variables were in the logarithmic form. The Equation (2) estimated the impact of the FDI inflow; the change in stock of domestic investment CHK, the exports of goods and services X, and the labor growth rate LBGR on the change in per capita GNP. This relationship was tested by means of bound testing approach. To implement this technique a joint significance test was performed as:

$\mathrm{H}_{0}: \delta_{1}=\delta_{2}=\delta_{3}=\delta_{4}=\delta_{5}=0$ against the alternative hypothesis

$\mathrm{H}_{1}: \delta_{1} \neq \delta_{2} \neq \delta_{3} \neq \delta_{4} \neq \delta_{5} \neq 0$

The bound testing approach is based on F-statistic under the null hypothesis of no cointegration among the examined variables regardless of as to whether they are purely I(0) or I(1). Pesaran et al (2001) computed two sets of critical values for the given level of the significance. One set assumes that all the variables are I(0) referred to as lower bound and other set assumes that they are all I(1) referred to as upper bound. There are three options for further proceeding. If the computed F-statistic exceeds the upper critical bound, value the $\mathrm{H}_{0}$ is rejected which implies that there exists the cointegration. If the F-statistic falls into the bounds, the test becomes inconclusive. In addition, if the F-statistic lays below the lower critical bounds values, it means no cointegration. In the first case when the cointegration is found we shall estimate the long-run relationship and the short-run relationship by modifying the equation (2) into the equation (3) and equation (4) respectively.

$$
\begin{aligned}
& \ln (G N P P C)_{t}=\alpha+\sum_{i=1}^{p} \phi_{i} \ln (G N P P C)_{t-i}+\sum_{i=0}^{p} \theta_{i} \ln (F D I)_{t-i}+\sum_{i=0}^{p} \lambda_{i} \ln (C H K)_{t-i} \\
& +\sum_{i=0}^{p} \psi_{i} \ln (X)_{t-i}+\sum_{i=0}^{p} \gamma_{i} \ln (L B G R)_{t-i}+\mu_{i} \ldots \ldots \ldots \ldots \ldots \ldots \ldots \ldots \ldots \ldots \ldots \ldots \ldots \ldots \ldots
\end{aligned}
$$

The orders of the lags in the ARDL model are selected by Akaike Information Criterion (AIC) before the model is estimated by the ordinary least squares (OLS). For the annual data, Pesaran and Shin (1999) recommended to choose a maximum of 2 lags. The ARDL specification of the short-run dynamics can be derived by formulating an error correction model of the following form:

$$
\begin{aligned}
& \Delta \ln (G N P P C)_{t}=\alpha+\sum_{i=1}^{p} \phi_{i} \Delta \ln (G N P P C)_{t-i}+\sum_{i=0}^{p} \theta_{i} \Delta \ln (F D I)_{t-i}+\sum_{i=0}^{p} \lambda_{i} \Delta \ln (C H K)_{t-i} \\
& +\sum_{i=0}^{p} \psi_{i} \Delta \ln (X)_{t-i}+\sum_{i=0}^{p} \gamma_{i} \Delta \ln (L B G R)_{t-i}+\delta(E C M)_{t-1}+v_{i}
\end{aligned}
$$

where $(\mathrm{ECM})_{\mathrm{t}-1}$ is the error correction term which is the lagged value of the residual of the equation of the long-run relationship like equation (3) in this case.

\section{Results}

In order to examine the influence of the FDI on the economic development of Pakistan equation (1) was formulated. Its ARDL formulation was equation (2). Before proceeding further, the order of integration of every variable included in these equations was checked by using the Augmented Dickey Fuller test for unit root. The results are reported in the following table.

Table 1: Results of Unit Root Test (FDI Effect on Economic Development)

\begin{tabular}{lllll}
\hline Variables & Intercept/Trend & Level & First Difference & Decision \\
\hline GNPPC & I & $3.0725^{* *}$ & -- & I $(0)$ \\
FDI & I & -1.8373 & $-4.9151^{*}$ & I(1) \\
CHK & I & $-4.0639^{*}$ & -- & I(0) \\
X & I & -2.5737 & $-4.9960^{*}$ & I $(1)$ \\
LBGR & I & $-4.3235^{*}$ & -- & I(0) \\
\hline
\end{tabular}

${ }^{*}$ Significant at the $1 \%$ level ${ }^{* *}$ Significant at the $5 \%$ level ${ }^{* * *}$ Significant at the $10 \%$ level 
As all the variables were mixture of me, (0) and me (1), it was appropriate to use the bound testing approach within the framework of the ARDL. For the purpose, equation (2) which was the ARDL formulation of the equation (1) was estimated and the results are shown in the following table.

Table 2: Effect of FDI on Economic Development

\begin{tabular}{|c|c|c|c|c|}
\hline \multicolumn{5}{|c|}{ Dependent Variable: DLOG(GNPPC) } \\
\hline \multicolumn{5}{|c|}{ Method: Least Squares } \\
\hline \multicolumn{5}{|l|}{ Sample: 19712009} \\
\hline \multicolumn{5}{|l|}{ Included observations: 35} \\
\hline \multicolumn{5}{|l|}{ Excluded observations: 4} \\
\hline Variable & Coefficient & Std. Error & t-Statistic & Prob. \\
\hline DLOG(GNPPC(-1)) & -0.302432 & 0.152106 & -1.988293 & 0.0594 \\
\hline DLOG(FDI) & 0.366936 & 0.163242 & 2.247806 & 0.0349 \\
\hline DLOG(CHK) & 0.159550 & 0.150129 & 1.062750 & 0.2994 \\
\hline $\operatorname{DLOG}(\mathrm{X})$ & 0.107771 & 0.754061 & 0.142920 & 0.8877 \\
\hline $\operatorname{DLOG}(X(-2))$ & 1.716843 & 0.609786 & 2.815483 & 0.0101 \\
\hline DLOG(LBGR) & 0.011703 & 0.065454 & 0.178795 & 0.8597 \\
\hline DLOG(LBGR(-1)) & -0.115593 & 0.073260 & -1.577852 & 0.1289 \\
\hline LOG(GNPPC(-1)) & -0.209288 & 0.144141 & -1.451968 & 0.1606 \\
\hline LOG(FDI(-1)) & 0.304047 & 0.152600 & 1.992445 & 0.0589 \\
\hline LOG(CHK(-1)) & 0.021543 & 0.187043 & 0.115176 & 0.9094 \\
\hline $\operatorname{LOG}(\mathrm{X}(-1))$ & 0.014585 & 0.589783 & 0.024730 & 0.9805 \\
\hline LOG(LBGR(-1)) & 0.206297 & 0.147479 & 1.398825 & 0.1758 \\
\hline $\mathrm{C}-2 \mathrm{~s}$ & 1.508979 & 1.601748 & 0.942083 & 0.3564 \\
\hline R-squared & 0.630713 & & & \\
\hline Adjusted R-squared & 0.429283 & & & \\
\hline Durbin-Watson stat & 2.107663 & & & \\
\hline F-statistic & 3.131184 & & & \\
\hline Prob(F-statistic) & 0.009825 & & & \\
\hline
\end{tabular}

The calculated value of the F-statistic is 3.13 which falls between the two critical bounds $(2.67$ as lower and 3.59 as upper at $10 \%$ level) set by Narayan (2004). This implies that the null hypothesis of the no cointegration is inconclusive. When the residual of the above estimated model was tested for the unit root it was found stationary. It means that the variables were somewhat co integrated. Now, for the long-run relationship, the equation (3) was estimated and the most insignificant variables were excluded for the parsimonious purpose. The value of the F-statistic for the long-run relationship was 78.67 which were greater than the upper bound critical value (5.97 at the $1 \%$ level) suggested by Narayan (2004). This implies that there exists long-run relationship. Then for the short run dynamics equation (4) was estimated. In this equation, the error correction term (ECM) $)_{t-1}$ was the lagged value of the residual of equation (3) of the longrun relationship. The results are shown in the following table:

Table 3: Long and Short-run Relationships

\begin{tabular}{llll}
\hline Variables & Long-run Coefficient & Variables & Short-run Coefficient \\
\hline LOG(GNPPC(-1)) & $0.582737^{*}$ & DLOG(GNPPC(-2)) & -0.201733 \\
LOG(FDI) & $0.425387^{* *}$ & DLOG(FDI) & 0.185611 \\
LOG(CHK) & $0.265089^{* * *}$ & DLOG(CHK) & 0.163215 \\
LOG(X) & 0.502859 & DLOG(X(-2)) & $1.233431^{* *}$ \\
C & 1.699416 & ECM(-1) & $-0.479709^{*}$ \\
\hline
\end{tabular}

* Significant at the $1 \%$ level ${ }^{* *}$ Significant at the $5 \%$ level ${ }^{* * *}$ Significant at the $10 \%$ level

The results of the above table are supporting the hypothesis that the FDI influences the economic development of Pakistan positively. The long-run coefficients of the FDI and CHK are positive and significant at $5 \%$ and $10 \%$ level of significance respectively while those for the short-run are positive but insignificant. The outcomes of the FDI endorse the findings of Shabbir Mahmoood (1992), Reisen \& Soto (2001), and Zhang (2001). The results about domestic investment are in line with that by Iqbal \& Zahid (1998) and suggest that 
the domestic capital as an input factor for the growth has been upholding its vital role. The coefficient of (X) showed positive but insignificant impact in the long-run. Its positive effect on the economic development might have been defused by parallel imports. Moreover, the exports of the developing countries like Pakistan have been slow to develop with the increase in trend of globalization. Comparing the impact of the FDI with that of the domestic investment, the coefficients of the FDI is greater than those of the domestic investment are. It implies that the FDI looks to have left more impact on the economic development than that of the domestic investment. These results support the findings of Zhang (2001) for China and Baharumshah Thanoon , (2006). The FDI has the potential to contribute to the economic development through the higher efficiency in the physical and the human capital. The findings highlight the importance of the FDI as being a vital determinant of the economic development and the findings are in line with the evidence which point to the strong contribution of the FDI to the economic development, especially in the Asian countries.

\section{Conclusion}

The foreign direct investment (FDI) has earned a lot of significance during the last two to three decades as being the source of capital, technology, skills and abilities. Its multifaceted impact on the host countries has been the main topic of the studies. The major one is on the economic development of the recipient country. The countries like Singapore, Hong Kong, Taiwan, and South Korea portrayed many success stories regarding its benefits in terms of economic development. Like other countries, Pakistan also took many steps to attract FDI and coined many policies for this purpose. As the different countries are achieving different results from FDI, so it is vital to study its impact in various context based on the policies being adopted there. The purpose of this study is to examine empirically the impact of FDI on the economic development of Pakistan. Along with the FDI, other independent variables were domestic investment, exports of goods and services, and labor force. The time series data for the period (1971-2009) were used. For the data analysis, the bound testing approach to cointegration within the framework of the Autoregressive Distributed Lag (ARDL) was used. The empirical results supported our hypothesis that FDI had positive and significant role in economic development of Pakistan. The domestic investment also showed the same results as that of FDI, however, the results of FDI were more robust indicating that FDI is more efficient than that of domestic investment. The impact of exports was positive but insignificant.

\section{References}

Ahmad, M. H., Alam, S. \& Butt, M. S. (2004). Foreign Direct Investment and Domestic Output in Pakistan. Nineteen Annual General Meeting, PIDE, Quaid-e-Azam University Islamabad, Pakistan.

Alfaro, L., Chanda, A., Ozcan, S. K. \& Sayek, S. (2006). How Does Foreign Direct Investment Promote Economic Growth? Exploring the Effect of Financial Markets on Linkages. Cambridge, MA, NBER Working Paper No W12522.

Atique, Z., Ahmad, M. H. \& Azhar, U. (2004). The Impact of FDI on Economic Growth Under Foreign Trade Regime: A Case Study of Pakistan. Pakistan Development Review, 43(4), 707-718.

Baharumshah, A. Z. \& Thanoon, M. A. M. (2006). Foreign capital flows and economic growth in East Asian countries. China Economic Review, 17, 70-83.

Balasubramanyam, V. N., Salisu, M. \& Sapsford, D. (1999). Foreign Direct Investment as an Engine of Growth. The Journal of International Trade and Economic Development, 8(1), 27-40.

Cypher, J. M. \& Dietz, J. L. (2004). The Process of Economic Development (2 ${ }^{\text {nd }}$ ed.). London and New York: Routledge.

Domar, E. D. (1946). Capital Expansion, Rate of Growth, and Employment. Econometrica, 14, 137-147.

Duasa, J. (2007). Determinants of Malaysian Trade Balance: An ARDL Bound Testing Approach. Journal of Economic Cooperation, 28(3), 21-40.

Dutta, M. (2005). China's Industrial Revolution: Challenges for a Macroeconomic Agenda. Journal of Asian Economics, 15, 1169-1202.

Government of Pakistan. (1996). Pakistan Economic Survey 1995-96. Economic Adviser's Wing, Finance Division, Government of Pakistan, Islamabad.

Government of Pakistan. (2006). Pakistan Economic Survey 2005-06. Economic Adviser's Wing, Finance Division, Government of Pakistan, Islamabad. 
Griffin, K. B. (1970). Foreign Capital, Domestic Savings and Development. Oxford Bulletin of Economics and Statistics, 32, 99-112.

Grossman, G. M. \& Helpman, E. (1991). Innovation and Growth in the Global Economy. Cambridge MA: The MIT Press.

Haddad, M. \& Harrison, A. (1993). Are There Positive Spillovers From Direct Foreign Investment? Evidence From Panel Data for Morocco. Journal of Development Economics, 42, 51-74.

Harrod, R. F. (1939). An Essay in Dynamic Theory. The Economic Journal, 49, 14-33.

Iqbal, Z. \& Zahid, G. M. (1998). Macroeconomic Determinants of Economic Growth in Pakistan, The Pakistan Development Review, 37(1), 125-148.

Khan, A. H. \& Kim Y. H. (1999). Foreign Direct Investment in Pakistan: Policy Issues and Operational Implications. EDRC Report Series No. 66.

Khan, M. A. (2007). Foreing Direct Investment and Economic Growth: The Role of Domestic Financial Sector. Pakistan Institute of Development Economics (PIDE) Working Paper 18.

Kojima, K. (1978). Direct Foreign Investment: A Japanese Model of Multinational Business Operations. London: Croom Helm.

Lall, S. (1980). Vertical Inter-firm Linkages in LDCs: An Empirical Study. Oxford Bulletin of Economic and Statistic, 42(3), 203-226.

Lekhi, R. K. (2008). The Economics of Development and Planning. New Delhi, India, Kalyani Publishers.

Lensink, R. \& Morrissey, O. (2006). Foreign Direct Investment: Flows, Volatility, and the Impact on Growth. Review of International Economics, 14(3), 478-493.

Lucas, R. E. J. (1988). On the Mechanics of Economic Development. Journal of Monetary Economics, 22(1), 342.

Makki, S. S. \& Sumwaru, A. (2004). Impact of Foreign Direct Investment and Trade on Economic Growth: Evidence From Developing Countries. American Journal of Agriculture Economics, 86(3), 795-801.

Markusen, J. \& Venables, A. (1999). Foreign Direct Investment as a Catalyst for Industrial Development. European Economic Review, 43(2), 335-56.

Narayan, P. K. (2004). Reformulating Critical Values for the Bounds F-statistics Approach to Cointegration: An Application to the Tourism Demand Model for Fiji. Discussion Papers, Department of Economics, Monash University, Australia.

Pesaran, M. H. \& Shin, Y. (1999). Autoregressive Distributed Lag Modeling Approach to Cointegration Analysis, Chapter 11, in: Storm, S., (ed.), Econometrics and Economic Theory in the $20^{\text {th }}$ Centrury: The Ragnar Frisch Centennial Symposium (Cambridge: Cambridge University Press)

Pesaran, M. H., Shin, Y. \& Smith, R. J. (2001). Bound Testing Approaches to the Analysis of the Long run Relationships. Journal of Applied Economic, 16, 289-326.

Rebelo, S. (1991). Long-run Policy Analysis and Long-run Growth. Journal of Political Economy, 96, 500-521.

Reisen, H. \& Soto, M. (2001). Which Types of Capital Inflows Foster Developing-Countries Growth? International Finance, 4(1), 1-14.

Romer, P. (1990). Endogenous Technological Change. Journal of Political Economy, 98(5), S71-102.

Ruffin, R. J. (1993). The Role of Foreign Investment in the Economic Growth of the Asian and Pacific Region. Asian Development Review, 11(1), 1-24.

Sahoo, P. (2006). Foreign Direct Investment in South Asia: Policy, Trends, Impact and Determinants. ADB Institute Discussion Paper No. 56.

Sahoo, D. \& Mathiyazhagan, M. K. (2003). Economic Growth in India: Does Foreign Direct Investment Matter? The Singapore Economic Review, 48(2), 51-171.

Seid, S. H. (2002). Global Regulations of Foreign Direct Investment. 131 Main Street Burington, VT 054015600 USA, Ashgate Publishing Company

Shabbir, T. \& Mahmood, A. (1992). The Effects of Foreign Private Investment on Economic Growth of Pakistan. The Pakistan Development Review, 31(4), 831-841.

Sharma, B. \& Gani, A. (2004). The Effects of Foreign Direct Investment on Human Development. Global Economy Journal, 4(2). http://www.aiecon.org/advanced/suggestedreadings/PDF/sug189.pdf

Sharma, S. \& Sharma, R. (2003). Globalization, Foreign Direct Investment, and Development. http://www.bimtech.ac.in/5_2.html.

SHRDC. (2007). Foreign Direct Investment and Human Resource Development: A Case Study of South Asia. SAARC Human Resource Development Centre Islamabad, Pakistan.

State Bank of Pakistan. (2005). Handbook of Statistics on Pakistan Economy 2005. http://www.sbp.gov.pk 
State Bank of Pakistan. (2010). Handbook of Statistics on Pakistan Economy 2010. http://www.sbp.gov.pk

UNCTAD. (2006). World Investment Report 2006: FDI From Developing and Transition Economies. New York and Geneva: United Nations.

Walz, U. (1997). Innovation, Foreign Direct Investment and Growth. Economica, 64, 63-79.

Wang, J. Y. (1990). Growth, Technology Transfer, and Long-Run Theory of International Capital Movements. Journal of International Economics, 29(3-4), 255-271.

Weisskof, T. E. (1972). The Impact of Foreign Capital Inflow on Domestic Savings in Underdeveloped Countries. Journal of International Economics, 2, 25-38.

World Bank. (2007). World Development Indicators 2007. CD-ROM, Washington, D.C. World Bank.

Yudaeva, K., Kozlov, K., Melentieva, N. \& Ponomareva, N. (2003). Does Foreign Ownership Matter? The Russian Experience. Economics of Transition, 11(3), 383-409.

Zhang, K. H. (2001). How Does Foreign Direct Investment Affect Economic Growth in China? Economics of Transition, 9(3), 679-693. 